harrisi. Lieutenant Carleton came on board to breakfast with us-a fine companion and a perfect gentleman. Indian war-whoops were heard by him and his men whilst embarking this morning after we left. We encamped at the mouth of Nishnebottana, a fine, clear stream. Went to the house of Mr. Beaumont, who has a pretty wife. We made a fine run of sixty or seventy miles.

The party passed Fort Leavenworth on the 10th and Independence on the 11th. Audubon complains of the beef they bought at New Brunswick on the 13th, saying that although it was excellent beef, it was very inferior to buffalo. They passed Jefferson City on the 16th and saw twenty-four deer not far below there. They reached St. Louis on the 19th. Audubon went by steamer from there and reached home near New York on November 6, 1843.

\title{
HUNTERS IN 1843 BUTCHERING BUFFALO
}

I have not given the particular manner in which the latter [butchering buffalo] is performed by the hunters of this country-I means the white hunters-and I will now try to do so. The moment that the buffalo is dead, three or four hunters, their faces and hands often covered with gunpowder, and with pipes lighted, place the animal on its belly, and by drawing out each fore and hind leg, fix the body so that it cannot fall down again; an incision is made near the root of the tail, immediately above the root in fact, and the skin cut to the neck, and taken off in the roughest manner imaginable, downwards and on both sides at the same time. The knives are going in all directions, and many wounds occur in the hands and fingers, but are rarely attended to at this time. The pipe of one man has perhaps given out, and with his bloody hands he takes the one of his nearest companion, who has his own hands equally bloody. Now one breaks in the skull of the bull, and with bloody fingers draws out the hot brains and swallows them with peculiar zest; another has now reached the liver, and is gobbling down enormous pieces of it; whilst, perhaps, a third who has come to the paunch, is feeding luxuriously on some-to me-disgusting-looking offal. But the main business proceeds.-Journal of J. J. Audubon, with notes by Coues, Vol I, p. 141. 
Copyright of Annals of Iowa is the property of State of Iowa, by \& through the State Historical Society of Iowa and its content may not be copied or emailed to multiple sites or posted to a listserv without the copyright holder's express written permission. However, users may print, download, or email articles for individual use. 